\title{
Editorial
}

We are most grateful to Dr W Zumkeller for enabling us to publish the abstracts of the proceedings of a recent symposium on "IGFs and Cancer", which took place on 15-17 September 2000. This meeting appears to have been a great success and covered a wide range of topics. In addition, a series of manuscripts derived from the symposium will be published in Molecular Pathology during the coming year. We are sure that readers will find the contents of
Dr Zumkeller's opening speech, regarding the history and development of the University of Halle, most interesting and in thanks to Dr Zumkeller we publish that speech below.

J CROCKER

D BURNETT

\section{The University of Halle through the centuries}

The roots of the university lie in the Leucorea, founded in 1502 in Wittenberg. The Alma mater Vitebergensis had Martin Luther and Philipp Melanchthon as their most famous scholars. It was also the most prestigious university in central Europe. Following the foundation of the University of Wittenberg in 1530/1531 by Cardinal Albrecht, the University of Halle was founded on 12 July 1694 with a spectacular baroque ceremony. Already in 1680, Michel Milie dit la Fleur, a Huguenot, founded a language school which in 1688 resulted in the so called Ritterschule, and the philosopher Christian Thomasius who was exiled from Leipzig started teaching the nobility from 1690 .

The foundation of the University of Halle stood at a turning point in German and European university history. Whereas in Wittenberg and Leipzig a strong Lutheran influence dominated, at the University of Halle academic freedom was considered to be essential for teaching and research. From the beginning, the four faculties had six internationally renowned academics: the lawyers Christian Thomasius and Samuel Stryck, the theologist August Hermann Francke, the philosopher Christian Wolff, and the physicians Friedrich Hoffman and Georg Ernst Stahl.

In the 18th century, Halle was among the four biggest universities in Germany. However, in the beginning, the medical faculty was the smallest of the four faculties. From 1693 until 1700, only 144 medical students were among the 2884 students at the University. Between 1731 and 1742, about 1500 students entered the university each year. Anton Wilhelm Amo from the Gold Cost (Ghana) was the first African student who in 1727 was enrolled at a European university. Notably, Dorothea Christiane Erxleben was the first woman in Germany to gain her thesis in medicine at the University of Halle. Friedrich Hoffmann was, beside Hermann Boerhaave in Leyden, the most famous physician of his time. Johann Junker, since 1716 physician at Francke's orphanage and since 1729 professor of medicine, started bedside teaching at this institution. With this reform, the Collegium clinicum Halense became an internationally renowned centre of practical training. There was a strong relationship between the FranckeFoundation and the medical faculty of the Fridericiana right from the beginning. Nursing facilities as well as medical care were provided. At this time, the medical faculty had only two professors, Friedrich Hoffmann (16601742) called "Aesculapius Hallensis" and Georg Ernst Stahl (1659-1734), who were among the most famous physicians during this period (Frühaufklärung). The laboratories of the Waisenhausapotheke for the production of medicines at the beginning of the 18th century were supervised by the medical professor Johann Juncker, whereas Friedrich Hoffmann investigated the medicines and published scientific papers. These medicines were exported as far as India and South Africa.

The Fridericiana, as the University of Halle was called since its foundation in 1694 by Friedrich III of Brandenburg, became already in the first decades a modern university. For poorer students, free meals were served and paid for by the nobility. Teaching was held mostly in the homes of the professors because the Fridericiana lacked a university building. The city council had opposed the foundation of the university because the poorer students promised little earnings but also because riots were feared, which then took place with the military. At one instance, in 1722, intolerant students stormed the home of Jewish citizens. They were punished by locking them up in the student "Karzer". Duels, although forbidden by law, often led to critical or deadly injuries.

At the end of the 18th century, the medical faculty gains importance as famous professors enter the University. In 1779, Philipp Friedrich Theodor Meckel (1756-1803) becomes professor of anatomy. His collection is still at the Institute of Anatomy. The war and closure of the university forces his successor, Justus Christian Loder (1753-1832) to leave for Moscow in 1806. Another outstanding professor of obstetrics and surgery was Johann Christian Rell (1759-1813), who in 1807 was among those representatives who reached an agreement leading to the reopening of the university. During Napoleonic rule, the university was closed twice but considerable donations were received from Great Britain and the USA. In 1817, the Universities of Halle and Wittenberg were unified and in the second half of the 19th century sciences and medicine experienced an upturn.

In the Francke Foundations, students from many countries were taught. The scholars returned as missionaries, teachers, or advisors. Anton Wilhelm Böhme, a pupil of Francke, was a preacher to Queen Anna. English students lived in a building at the Foundations, which is still today called the "English House". Francke had a correspondence with Cotton Mather, leader of the puritans in Boston. Heinrich Melchior Mühlenberg who was a theology student at the university went to America as a priest. At the time of his death, his significance as the virtual founder of the Lutheran church in America was recognised on all sides, and his fame has grown with the church. It is said that no family in Pennsylvania gave more important men to 
public life than the Mühlenbergs. One of his sons, Johann Peter Gabriel Mühlenberg, became a priest in Woodstock, Virginia, and gained fame as a brigadier general in the continental army. Later he was a member of the House of Representatives and a US senator. His brother, Friedrich August Conrad, became the First Speaker of the House of Representatives and his oldest brother, Gotthilf Heinrich Ernst was a famous botanist in the USA. Another former student, Franz Lieber, who had emigrated to the USA in order to evade persecution for his liberal beliefs edited the first American encyclopaedia, the "Encyclopaedia Americana" and became a professor of history at the Columbia University in South Carolina, which since 1992 has maintained relations with our University. The Library of Congress in Washington DC and the Lutheran Archive Center Philadelphia contains ample archive material on these Halle-America relations.

In 1933, following the 450th birthday of Martin Luther, the University received its present name. More importantly, the Nazi regime began in 1933 with a drastic change of the university constitution and with the expulsion of so called politically and "racially" undesirable individuals from the university. In February 1945, the activities at the university came to a halt as a result of World War II. Reopened in February 1946, the University adopted a communist ideology. On 11 May 1990, the first free elections took place in more than 50 years. Germany was reunited on 3 October 1990. Today, the Martin-LutherUniversity maintains many partnerships with universities throughout the world and hosts students from many countries.

This symposium has to be seen in a historical and political context but it is also timely from a scientific standpoint. In fact, the past few years have seen a radical alteration in our understanding of the role of IGFs in the neoplastic process and the new challenge is to use this new understanding to diagnose and combat cancer. It is hoped that the meeting will give new inspiration for research and enhance scientific collaboration. I am indebted to all the participants for their contributions and discussions.

Thus, a university with a long history of science welcomes all the participants of the symposium "IGFs and Cancer" and wishes a fruitful exchanges of ideas.

W ZUMKELLER 